\title{
Traditional knowledge of medicinal plants in the Kampung Orang Asli Donglai Baru, Hulu Langat, Malaysia
}

\author{
MOHD RAZNAN RAMLI ${ }^{1, \boldsymbol{v}}$, SORAYYA MALEK ${ }^{2}$, POZI MILOW ${ }^{1}$, NURUL JANNAH AZIZ ${ }^{2}$ \\ ${ }^{1}$ Environmental Management Program, Institute of Biological Sciences, Faculty of Science, Universiti Malaya. 50603, Kuala Lumpur, Malaysia. \\ Tel.: +603-79676777, `email: raznan83@gmail.com \\ ${ }^{2}$ Bioinformatics Program, Institute of Biological Sciences, Faculty of Science, Universiti Malaya. 50603, Kuala Lumpur, Malaysia
}

Manuscript received: 3 February 2021. Revision accepted: 15 February 2021.

\begin{abstract}
Ramli MP, Malek S, Milow P, Aziz NJ. 2021. Traditional knowledge of medicinal plants in the Kampung Orang Asli Donglai Baru, Hulu Langat, Malaysia. Biodiversitas 22: 1304-1309. Documentation on traditional knowledge of medicinal plants is important before it is completely exhausted by the loss of natural habitats surrounding it and the passing away of older generations. In this study, an ethnobotanical survey for the medicinal plants in the Kampung Orang Asli Donglai Baru, Hulu Langat, Selangor, Malaysia was carried out. A semi-structured interview was prepared to record the medicinal uses of the local medicinal plants in the study area. The information such as the Orang Asli local name, parts used for medication, methods of preparation, and type of ailments were all collected. The total numbers of recorded species in the study sites were 39 species belonging to 22 families. The families Zingiberaceae, Marantaceae, Leguminosae, Vitaceae, Lamiaceae, Melastomataceae, and Araceae have recorded the highest species of medicinal plants. The most frequently utilized plant parts were the leaves $(25 \%)$ followed by roots $(20 \%)$, whole plants $(10 \%)$, fruit $(5 \%)$ and flowers $(2.5 \%)$. Gastrointestinal problems including stomach ache, diarrhea, indigestion and bloating were among the most frequent ailments treated with the medical plants. This study revealed that many medicinal plants are still broadly used by the community for treating various diseases in ailments. Further investigation needs to be carried out to explore the potential of these plants in scientific usage.
\end{abstract}

Keywords: Ethnobotany, medicine plants, Orang Asli, Kampung Orang Asli Donglai Baru

\section{INTRODUCTION}

Nowadays, it is noticeable that traditional knowledge of medicinal plants used as was embedded in rural and indigenous people has slowly been eroding with modernization. The presences of public healthcare, economic development and current systems of formal education have also led to loss of traditional knowledge of medicinal plants (Saynes-Vasquez et al. 2013). This is evident from the research of an indigenous community in Ecuador by Weckmuller (2019), where young people do not have as much knowledge of medicinal plants as older people. In some cases, there is still lack of written documents of local knowledge of medicinal plants in the scientific literature (Napagoda et al. 2018). Study by $\mathrm{Hu}$ et al. (2020) indicated that the traditional knowledge of medicinal plants among Mulam community in Guangxi, China is threatened due to lack of written records, conservative inheritance patterns, rapid economic development and low interest in traditional medicinal knowledge among young people. In addition, some medicinal plants are increasingly at risk of habitat loss due to environmental degradation, and over-harvesting of established medicinal plants. $\mathrm{Hu}$ et al (2020) reported agricultural activities, firewood collection, overgrazing, logging, and overharvesting of medicinal plants resulted in a decrease in medicinal plant resources and associated traditional knowledge in Guangxi, China.
The importance of traditional knowledge of medicinal plants has been recognized as a potentially valuable source of leads for drug discovery. The active compounds in most parts of the medicinal plants including seeds, roots, leaves, fruits, skins, flowers or even the whole plant have direct or indirect therapeutic effects and are used as medicinal agents (Jamshidi-Kia et al. 2018). For instance, Catharanthus roseus (L.) G. Don has been widely used as a traditional medicine to treat various diseases in many countries. Ochwang et al. (2014) reported that the aqueous extract of the leaf or the whole plant is used by Kenyans as complementary and alternative therapies for various types of cancer including throat, stomach and esophageal cancers. Semenya et al. (2013) reported that dried root of Catharanthus roseus (L.) G. Don is grounded and decocted for curing gonorrhea in Limpopo Province, South Africa. In Vietnam, the whole plant is boiled with water and taken orally to treat diabetes, hypertension, dysentery, and cancer (Vo 2012). Remarkably, the potential health benefits of phytochemicals extracted from this plant have been proved from scientific evidence. It has been reported that the vinblastine and vincristine isolated from this plant were the first plant-derived anticancer agents deployed for clinical use (Pham et al. 2020).

In Malaysia, documentation of traditional knowledge on medicinal plants among the Orang Asli tribe is still scanty. Although there are few reports on the documentation on the traditional use of medicinal plants in a few other regions (Mohammad et al. 2012; Sabran et al. 2016; Zaki et al. 2019), there is currently no literature 
available on the report in this area. Orang Asli are minority groups and indigenous peoples of Peninsular Malaysia. According to Khor et al. (2019), most Orang Asli resides in settlements which are often located in the forest or forestfringe areas and depend significantly on surrounding forests where they forage for wild fruits, ornamental plants, and wood products, and hunt wild animals as a source of income and food. There are three main groups of Orang Asli in Peninsular Malaysia namely Senoi, Proto-Malays, and Negrito, and eighteen sub-groups including Semai, Temiar, Jahut, Che Wong, Mahmeri, Semoqberi, Temuan, Semelai, Jakun, Kanaq, Kuala, Seletar, Kensiu, Kintak, Jahai, Lanoh, Mendriq and Bateq (Hussain et al. 2017).

Temuan tribe is one of the groups of Proto-Malays who originated from middle Asia and settled in Peninsular Malaysia around 4000 years ago (Fix 1995; Lim et al. 2010). They reside in the jungle areas near the hillside, and still use their natural resources around them for food, daily use and medical purposes. They are therefore among the most knowledgeable Orang Asli tribe on the use of natural resources, especially for medicinal purposes. While there have been several other Temuan studies, there have been few that explicitly identified their use of medicinal plants. Among them are Ong (2012a), Azliza et al. (2012), Ismail et al. (2020), and Ahmad et al. (2020). The objective of the current study is to documents the traditional knowledge of medicinal plants used by the Temuan tribe in Kampung Orang Asli Donglai Baru, Hulu Langat. The significance of this study is to preserve the traditional knowledge before it is completely exhausted by the loss of natural habitats surrounding it and the passing away of older generations.

\section{MATERIALS AND METHODS}

The study was conducted in the year 2018 in a village known as Kampung Orang Ali Donglai Baru and lies between $3.114^{\circ} \mathrm{N}$ to $3.1176^{\circ} \mathrm{N}$ latitude and $101.908^{\circ} \mathrm{E}$ to $101.912^{\circ} \mathrm{E}$ longitude in the Hulu Langat municipality, in the state of Selangor, Malaysia (Figure 1). The village lies approximately at 200 meters above sea level and extends 65.53 ha and only comprises with Temuan tribe. It has a tropical climate with temperatures recorded from $28^{\circ} \mathrm{C}$ to $32^{\circ} \mathrm{C}$ through the whole year and $2,000 \mathrm{~mm}$ to $2,500 \mathrm{~mm}$ of precipitation annually. Land cover includes rubber tree plantations and natural forests. The population, comprising of 279 inhabitants with 59 heads of households. Most of them are working as rubber tappers and also remain strongly dependent on forest resources as source of income and medicine, owing to the vast traditional knowledge among them.

Semi-structured interviews were used to gather information on traditional knowledge of medicinal plants regarding the utilization of medicinal plant species, their usefulness, the utilized part, mode of preparation, or method of processing the plants. All of the head family units were interviewed, except in households that did not agree to participate. Thirty key informants, 19 men and 11 women with ages ranging from 43 to 72 years were interviewed and the research background and purpose were explained prior to each interview. Plant pictures were taken during the field observation. Details on the traditional knowledge were summarizing in Table 1.

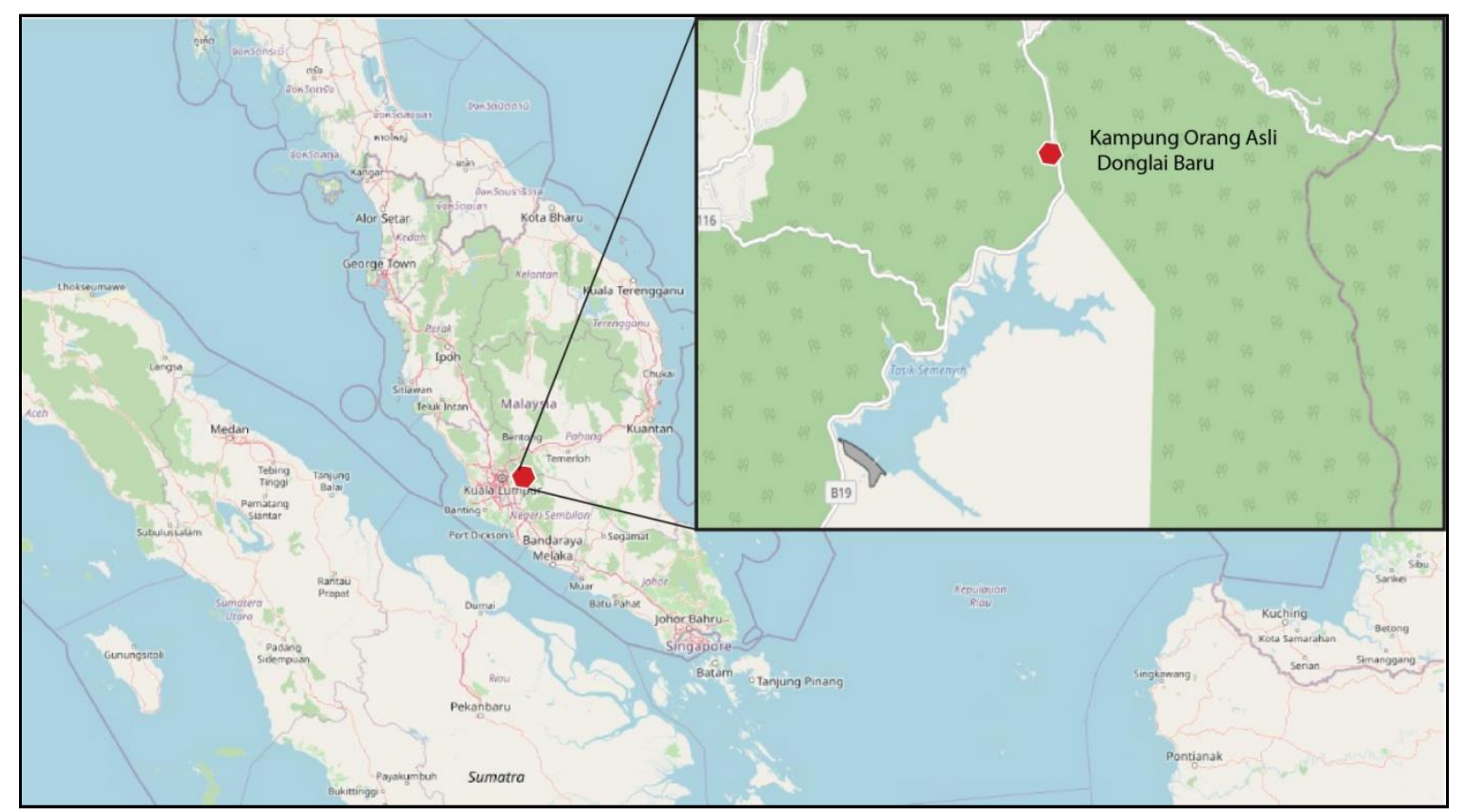

Figure 1. Location of Kampung Orang Asli Donglai Baru, Hulu Langat, Selangor lies between $3.114^{\circ} \mathrm{N}$ to $3.1176^{\circ} \mathrm{N}$ latitude and $101.908^{\circ} \mathrm{E}$ to $101.912^{\circ} \mathrm{E}$ longitude. 


\section{RESULTS AND DISCUSSIONS}

In the present study a total of 39 plant species used in traditional medicine by the Temuan tribe of Kampung Donglai Baru belonging to 37 genera and 31 plant families was recorded (Table 1). The total species recorded in this study is less compared to other Temuan villages in Gombak, Selangor and Negeri Sembilan. Azliza et al. (2012) reported that the Temuan of Ulu Kuang village, Gombak uses 49 species of medicinal plants. Ong et al. (2011a) noted the Temuan in a village of Negeri Sembilan uses 56 species of medicinal plants. However, the number of medicinal plant species recorded in this study is higher than those recorded for several local communities of other Orang Asli ethnic groups such as the Jah Hut of a village in Jerantut, Pahang and the Semai of a village in Tapah, Perak. Zaki et al. (2019) recorded that the Temiar community only uses 18 species of medicinal plants. Ong et al. (2012) reported that the Semai ethnic group only uses 37 species of medicinal plants.

Compared to other indigenous communities in other parts of the world, the overall species recorded in this study are considered to be lower. Sulaiman et al. (2020) indicated that the tribal community of Gokand Valley, Pakistan uses 109 species of medicinal plants in the treatment of various ailments. Tefera and Yihune (2018) reported that the indigenous people in Tenta District, Ethiopia uses 121 species of medicinal plants. Gonfa et al. (2020) noted that the indigenous people of Gera district, Ethiopia uses 63 medicinal plants. Sharafatmandrad and Mashizi (2020) recorded that the indigenous community in south-eastern Iran uses 156 species of medicinal plants. The lower total species recorded in this study may be due to the low total number of key informants interviewed. As a comparison, 168 key informants were interviewed by Sulaiman et al. (2020), 96 key informants were interviewed by Tefera and Yihune (2018), 60 key informants were interviewed by
Gonfa et al. (2020) and 85 key informants were interviewed by Sharafatmandrad and Mashizi (2020). In this study, only 30 key informants were interviewed.

The largest proportion of medicinal plants belonged to the families Zingiberaceae, Marantaceae, Leguminosae, Vitaceae, Lamiaceae, Melastomataceae, and Araceae. The present study also is in agreement with other studies that Zingiberaceae is one of the major families of medicinal plants used by Orang Asli community in Peninsular Malaysia. Mohammad et al. (2012) indicated that Zingiberaceae, Asparagaceae, Rubiaceae and Sapindaceae are among the highest plant families of medicinal plants used by Orang Asli community in Lubuk Ulu Legong, Kedah. Zaki et al. (2019) reported that Zingiberacea was the most represented family in medicinal plant species used followed by Rutaceae, Euphorbiaceae, Annonaceae, and Umbelliferae among Orang Asli in Kampung Pasik, Kelantan. Azliza et al. (2012) indicated that Zingiberaceae, Fabaceae, Annonaceae, Piperaceae, Musaceae, Asteraceae, and Annonaceae.

Leaves, roots, flowers, fruits, rhizomes were the plant parts used for medicinal preparations and in some cases, the whole plants are used, including the roots. The most frequently utilized plant parts were the leaves $(25 \%)$ followed by roots $(20 \%)$, whole plants $(10 \%)$, fruit $(5 \%)$ and flowers $(2.5 \%)$. Gastrointestinal problems including stomach ache, diarrhea, indigestion, and bloating were among the most frequent ailments treated with the medical plants (23\% of all remedies). It is followed by hypertension (18\%), increasing of immune system (14\%), diabetes, muscle pain and poison antidote (7\%), woman health, dermatological complaints and fever (5\%), and other health problem $(2 \%)$. The main administration routes of the remedies were taken orally as shown in Figure 2 including drink, eat and chew (66.64\%) and topical application (34.15\%). The most common method of preparation is decoction $(60.9 \%)$ as shown in Figure 3.

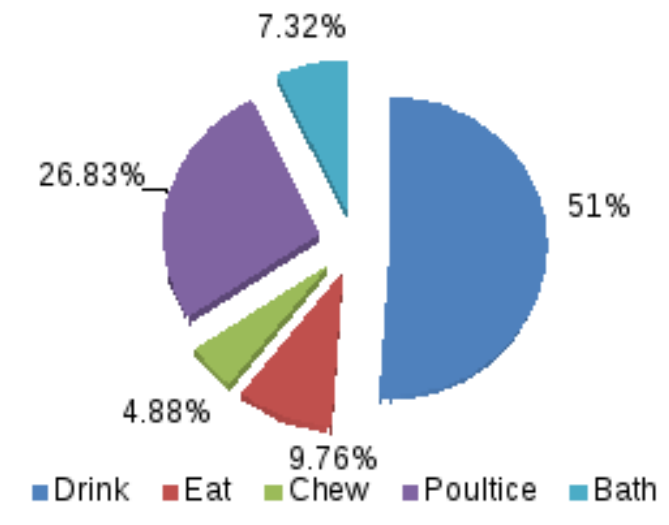

Figure 2. Percentage method of usage of medicinal plants

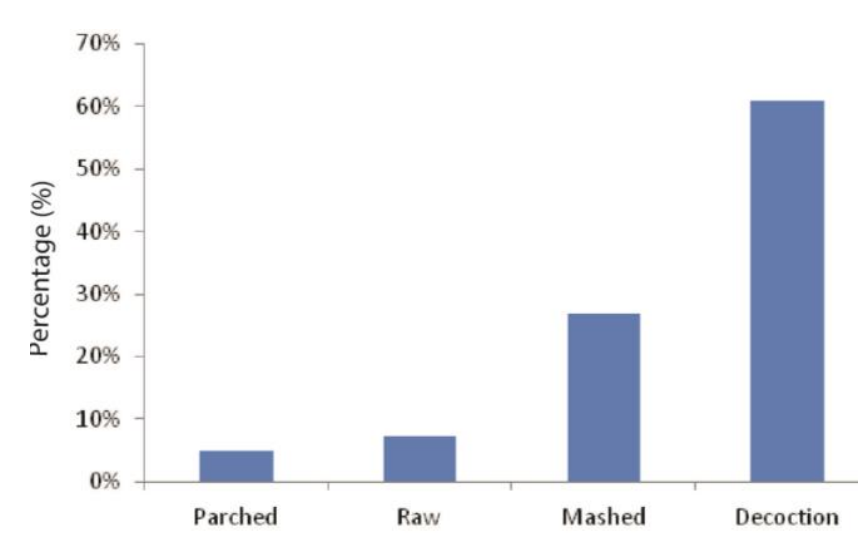

Figure 3. Method preparation of medicinal plants 
Table 1. Utilization of plant species as traditional medicine by Temuan tribe in Kampung Orang Asli Donglai Baru, Hulu Langat, Selangor, Malaysia

\begin{tabular}{|c|c|c|c|c|}
\hline Scientific name & Local name & Parts (s) used & Preparation(s) & Ailments \\
\hline Acorus calamus L. & Jerangau & Fruit/rhizome & Decoction & $\begin{array}{l}\text { Increase immune body } \\
\text { system/ Healing rituals }\end{array}$ \\
\hline Archidendron jiringa (Jack) I.C.Nielsen & Pokok Jering & Root & Decoction & Hypertension \\
\hline Bauhinia bassacensis Pierre ex Gagnepain & Akar dali & Root & Decoction & $\begin{array}{l}\text { Increase immune body } \\
\text { system }\end{array}$ \\
\hline Boesenbergia pandurate (Roxb.) Schltr & Daun kuyen & Root/rhizome & Decoction & Fever \\
\hline Carica papaya $L$. & Daun betik & Leaves & Raw & Hypertension \\
\hline Catharanthus roseus (L.) G.Don & Kemunting cina & Leaves & Decoction & $\begin{array}{l}\text { Increase immune body } \\
\text { system }\end{array}$ \\
\hline Centella asiatica (L.) Urb. & Pegaga & Leaves & Decoction & Hypertension \\
\hline Chassalia curviflora Thwaites & Bulut & Leaves & Decoction & Constipation disease \\
\hline Cheilocostus speciosus (J.König) C.Specht & Setawar & Leaves & Decoction & $\begin{array}{l}\text { Increase immune body } \\
\text { system }\end{array}$ \\
\hline Clidemia hirta (L.) D. Don & Senduduk Buluh & Leaves & Mashed & $\begin{array}{l}\text { Reduce wound after } \\
\text { childbirth }\end{array}$ \\
\hline Coleus amboinicus Lour. & Pokok hati-hati & Leaves & Decoction & $\begin{array}{l}\text { Prevention of } \\
\text { constipation }\end{array}$ \\
\hline Crinum asiaticum $\mathrm{L}$ & $\begin{array}{l}\text { Daun Tembaga } \\
\text { Suasa }\end{array}$ & Leaves & Parched & Fracture, muscle pain \\
\hline Curcuma zedoaria (Christm.) Roscoe & Kunyit Putih & Leaves & Mashed & Skin disease \\
\hline Cyathula prostrata (L.) Blume & Daun cirit-birit & Leaves & Decoction & Reduce diarrhea \\
\hline Donax canniformis (G.Forst.) K.Schum. & Daun Bemban & Leaves & Mashed & Refreshing eye drop \\
\hline Elettariopsis curtisii Baker & Semomok & Whole plants & Decoction & Bloating \\
\hline Eurycoma longifolia Jack & Tongkat Ali & Roots & Decoction & $\begin{array}{l}\text { Diabetes, hypetension, } \\
\text { muscle pain }\end{array}$ \\
\hline Ficus abscondita C.C.Berg & $\begin{array}{l}\text { Akar tengkuk } \\
\text { jawak }\end{array}$ & Root & Decoction & $\begin{array}{l}\text { Reduce stomachache } \\
\text { and waist pain }\end{array}$ \\
\hline Henckelia platypus (C.B.Clarke) A.Weber & Akar Meriam geget & Whole plant & Decoction & $\begin{array}{l}\text { Herbs for women after } \\
\text { childbirth }\end{array}$ \\
\hline Hibiscus rosa- sinensis.L. & Bunga raya & Flower & Mashed & Reduce stomachache \\
\hline Homalomena sagittifolia Jungh. ex Schott & Pokok kemoyang & Leaves & Parched & Fever \\
\hline Iguanura geonomiformis Mart. & Legung Baung & Leaves & Decoction & Reduce worms diseases \\
\hline Labisia pumila (Blume) Mez & $\begin{array}{l}\text { Kacip fatimah/ } \\
\text { Meriyan }\end{array}$ & Leaves + root & Decoction & $\begin{array}{l}\text { Increase immune body } \\
\text { system for women } \\
\text { (after childbirth) }\end{array}$ \\
\hline Lawsonia inermis (L.) Pers. & Inai & Leaves & Decoction & $\begin{array}{l}\text { Reduce headache } \\
\text { (Bath) }\end{array}$ \\
\hline Leea indica (Burm. f.) Merr. & Pokok Mali & Leaves & Decoction & Hypertension \\
\hline Maranta arundinacea $\mathrm{L}$. & Ubi Larut & Root & Decoction & Poison antidote \\
\hline Muehlenbeckia platyclados. Meisn. & Pokok lipan & Leaves & Mashed & Reduce centipede's bite \\
\hline Orthosiphon stamineus Benth & Misai kucing & Leaves & Decoction & Diabetes, hypertension \\
\hline Phyllagathis rotundifolia (Jack) Blum. & Tapak Gajah & Leaves & Mashed & Stomach-ache \\
\hline Piper sarmentosum Roxb & Sirih & Leaves & Raw & Fever, Hypertension \\
\hline Psidium guajava $\mathrm{L}$. & Daun jambu batu & Leaves & Decoction & Reduces stomachache \\
\hline Senna alata (L.) Roxb. & $\begin{array}{l}\text { Daun linggang } \\
\text { (ubat kurat) }\end{array}$ & Leaves & Mashed & Dermatophytosis \\
\hline Smilax myosotiflora A.DC & Ubi jaga & Fruits & Decoction & Diabetes \\
\hline Solanum ferox $\mathrm{L}$ & Terung satok & Fruits-whole plants & Raw & Hypertension, spiritual \\
\hline Spilanthes acmella (L.) & Subang Nenek & Leaves & Mashed & Toothache \\
\hline Tacca integrifolia Ker Gawl. & Misai baung & Leaves & Mashed & Skin pain \\
\hline Tetracera scandens (L.) Merr & Mempelas akar & Root & Decoction & Throat infection \\
\hline Vitex negundo L. & Daun lemuni & Leaves & Mashed & Reduces stress \\
\hline Zingiber cassumunar Roxb. & Bonglai & Whole plant & Decoction & Bloating \\
\hline
\end{tabular}

The findings recorded a total of 9 species of plants are used in the treatment of gastrointestinal problems. Among the species of plants used by the villagers are including Chasallia curviflora Thwaites, Coleus amboinicus Lour., Cyathula prostrata (L.) Blume, Elettariopsis curtisii Baker, Ficus abscondita C.C.Berg, Hibiscus rosa- sinensis.L.,
Phyllagathis rotundifolia (Jack) Blum., Psidium guajava L., Zingiber cassumunar Roxb. Acc. The plants species recorded in this study for the treatment of gastrointestinal problems is higher compared to other Temuan village. Ong et al. (2011a) reported only three species of plants are used by Temuan tribe in Kampung Tering, Negeri Sembilan 
including Apama tomentosa Eng, Peucedanum japonica Thunb and Psidium guajava L. Ong et al. (2011b) reported only four species of plants are used by Temuan tribe in Kampung Jeram Kedah, Negeri Sembilan in the treatment of gastrointestinal problems including Aloe barbadensis Mill, Eugenia valdevenosa Duthie, Phyllagathis rotundifolia (Jack.) Bl and Psidium guajava L. However, the finding in this study is in agreement with Ong et al. (2011a, 2011b) which indicated that Psidium guajava L is one of the most common plants used by the Temuan tribe to treat gastrointestinal problems.

Seven species recorded in this study are used by the villagers in the treatment of hypertension. The plant species are including Archidendron jiringa (Jack) I.C.Nielsen, Carica papaya L., Centella asiatica (L.) Urb., Eurycoma longifolia Jack, Leea indica (Burm. f.) Merr., Orthosiphon stamineus Benth and Solanum ferox L. The plants recorded in the treatment of hypertension by Temuan tribe in this study are lower compared to the other Temuan village report by Ong et al. (2011a). The Temuan tribe in the Kampung Tering, Negeri Sembilan used ten species of plants in the treatment of hypertension which is including Apama tomentosa Engl, Archidendron jiringa (Jack) I.C.Nielsen, Averrhoa carambola L., Bonnaya veronicaefolia Spreng, Catharanthus roseus (L.)Don, Centella asiatica (L.) Urban, Ficus aurantiaca Griff., Parkia speciosa Hassk., Striga asiatica (L.) Kuntze and Tinospora crispa (L.)Miers. ex Hk.f. and Thoms (Ong t al 2011a). However, there are two species recorded that are similar in both villages in the treatment of hypertension. The species are Archidendron jiringa (Jack) I.C.Nielsen and Centella asiatica (L.) Urban. Study by Azliza et al. (2012) in Kampung Ulu Kuang, Selangor also indicated that the Temuan tribe in the area are using Archidendron jiringa (Jack) I.C.Nielsen and Eurycoma longifolia Jack in the treatment of hypertension which is similar in this study.

From the result, it shows that Clidemia hirta (L.) D. Don, Homalomena sagittifolia Jungh. ex Schott, Carica papaya L, Henckelia platypus (C.B.Clarke) A.Weber, Leea indica (Burm. f.) Merr, Phyllagathis rotundifolia (Jack) Blum and Zingiber cassumunar Roxb are commonly used by the villagers as compared to other species. Clidemia hirta (L.) D. Don is used by the villagers as a natural remedy to close up wounds and stop bleeding after childbirth. This finding is in agreement with the report by Lopez (2016) which indicated that the crushed leaves Clidemia hirta (L.) D. Don mixed with saliva are applied as a poultice on wounds to stop bleeding in Malaysia. Rizki et al. (2019) also reported that indigenous people of West Pasaman, Indonesia crushed the leaves of the plant and applied tropically on the wound to stop bleeding. In the meantime, the roots and leaves of Homalomena sagittifolia Jungh. ex Schott is used in the treatment of fever. Carica papaya $\mathrm{L}$ is used in the treatment of hypertension, Henckelia platypus (C.B.Clarke) A.Weber is used in the treatment for women after childbirth, Leea indica (Burm. f.) Merr is used in the treatment of hypertension, Phyllagathis rotundifolia (Jack) Blum is used in the treatment of stomach-ache and Zingiber cassumunar Roxb is used in the treatment of bloating. However, there are slight differences in the ailments treat by the plants in other Temuan villages and other Orang Ali tribe. Ong et al. (2011b) reported that Carica papaya $\mathrm{L}$ is used in the treatment of malarial fever and Phyllagathis rotundifolia (Jack) Blum is used in the treatment of stomach discomfort among juvenile. Carica papaya L is reported by Muhammad et al. (2012) is used by Kensiu tribe in Kampung Lubuk Ulu Legong, Kedah in the treatment of cough. Azliza et al. (2012) reported that Leea indica (Burm. f.) Merr is used in the treatment of wounds by Temuan tribe in Kampung Ulu Kuang. Leea indica (Burm. f.) Merr is reported by Muhammad et al. (2012) in the treatment of diabetes.

Semi-structured interviews and field surveys were among the most method used in ethnobotanical studies. These methods were used in this study and most of the recent studies also still use these methods to obtain information on traditional knowledge of the use of medicinal plant species, their usefulness, the part used and the method of preparation. Jadid et al (2020) used semistructured interviews with informants of Tengger tribe who knew or used plants as medicine in Ngadisari village, Indonesia. Kassa et al. (2020) prepared semi-structured interview method to retrieve qualitative and quantitative ethnobotanical data from informants of Sheka community in southwestern Ethiopia. Islam et al. (2020) also used field surveys and semi-structured interviews to investigate the ethnobotany of medicinal plants used by Rakhine indigenous communities in Patuakhali and Barguna District of Southern Bangladesh.

To conclude, this current ethnobotanical field survey carried out among the Orang Asli living in the Kampung Donglai Baru region of Selangor, Malaysia reveals that many medicinal plants are still broadly used by the community for treating various disease in ailments. These plants are needed for future studies to determine the chemical composition and its efficacy in the treatment of various diseases. Since Zingiberaceae are indicated as the most common family of plants use in traditional medicine in this finding and other studies, this should encourage further study need to be carried out to explore the potential of this family in scientific medicinal investigation. Documentation of traditional knowledge on the use of medicinal plants among local community is necessary to preserve the valuable knowledge from being eroded. Some of the medicinal knowledge on the uses of plants was buried together with the previous generations due to lack of knowledge and interest among the younger generations.

\section{ACKNOWLEDGEMENTS}

We thank the University of Malaya and the Ministry of Education of Malaysia for providing facilities and funds that enable this study to be carried out. Publication of this article was funded by PG072-2013A, RF193-12SUS and LL023-16SUS provided by University of Malaya and MyBrain 15 Scholarship provided by Ministry of Education of Malaysia. This study is also to be a part of a $\mathrm{Ph}$.D. contribution of the first author. 


\section{REFERENCES}

Ahmad NA. Sabran ST, Mazlun MH, Bakar MFA, Kormin F, Fuzi SFZM 2020. Traditional knowledge and usage of edible plants among Temuan community in Gunung Ledang Johor National Park, Malaysia. J Sustain Nat Resour 1 (2): 27-31.

Azliza M, Ong H, Vikineswary S, Noorlidah A, Haron N. 2012. Ethnomedicinal resources used by the Temuan in Ulu Kuang Village. Stud Ethno-Med 6 (1): 17-22.

Fix AG. 1995. Malayan paleosociology: Implications for patterns of genetic variation among the Orang Asli. Am Anthropol 97: 313-323.

Gonfa N, Tulu D, Hundera K, Raga D. 2020. Ethnobotanical study of medicinal plants, its utilization, and conservation by indigenous people of Gera district, Ethiopia indigenous people of Gera District, Ethiopia. Cogent Food Agric 6 (1): 1852716.

Hu R, Lin C, Xu W, Lui Y, Long C. 2020. Ethnobotanical study on medicinal plants used by Mulam people in Guangxi, China. 2020. J Ethnobiol Ethnomed 16 (40): 1-50.

Hussain TPRS, Krishnasamy DS, Hassan AAG. 2017. Distribution and demography of the Orang Asli in Malaysia. Intl J Humanities Soc Sci Invention 6 (1): 40-45.

Islam ATMR, Hasan M, Islam T, Rahman A, Mitra S, Das SK. 2020 Ethnobotany of medicinal plants used by Rakhine indigenous communities in Patuakhali and Barguna District of Southern Bangladesh. J Evid-Based Integr Med 25: 1-27.

Ismail NH, Pa'ee F, Salleh NAM. 2020. Documentation of plants used for postnatal care by Temuan community in Taman Negara Johor Gunung Ledang. J Solid State Technol 63 (3): 1-7

Jadid N, Kurniawan E, Himayani CES, Andriyani, Prasetyowati I, Purwani KI, Muslihatin W, Hidayati D, Tjahjaningrum ITD. 2020. An ethnobotanical study of medicinal plants used by the Tengger tribe in Ngadisari village, Indonesia. PLoS ONE 15 (7): e0235886. DOI: 10.1371/journal.pone.0235886.

Jamshidi-Kia F, Lorigooini Z, Amini-Khoei H. 2018. Medicinal plants: Past history and future perspective. J Herbmed Pharmacol 7( 1): 1-7.

Kassa Z, Asfaw Z, Demissew S. 2020. An ethnobotanical study of medicinal plants in Sheka Zone of Southern Nations Nationalities and Peoples Regional State, Ethiopia. J Ethnobiol Ethnomed 16 (7): 1-15.

Khor CS, Hassan H, Rahim NFM, Chandren JR, Nore SS, Johari J, Loong SK, Jamil JA, Khoo JJ, Lee HY, Pike BL Ping WL Lin YAL, Abubakar S. 2019. Seroprevalence of Borrelia burgdorferi among the indigenous people (Orang Asli) of Peninsular Malaysia. J Infect Develop Ctries 13 (5): 449-454

Lim Ls, Ang KC, Mahani MC, Shahrom AW, Md-Zain BM. 2010. Mitochondrial DNA polymorphism and phylogenetic relationships of Proto Malays in Peninsular Malaysia. J Biol Sci 10 (2): 71-83.

Lopez T, Corbin C, Falguieres A, Doussot J, Montguillon J, Hagege D, Hano C, Laine E. 2016. Secondary metabolite accumulation, antibacterial and antioxidant properties of in vitro propagated Clidemia hirta L.extracts are influenced by the basal culture medium. C R Chimie 19 (9): 1071-1076.

Mohammad NS, Milow P, Ong HC. 2012. Traditional medicinal plants used by the Kensiu Tribe of Lubuk Ulu Legong, Kedah, Malaysia. Ethno Med 6 (3): 149-153.

Napagoda MT, Sundarapperuma T, Fonseka D, Amarasiri S, Gunaratna P. 2018. An ethnobotanical study of the medicinal plants used as anti- inflammatory remedies in Gempaha District, Western Province, Sri Lanka. Scientifica. DOI: 10.1155/2018/939505

Ochwang DO, Kimwele CN, Oduma JA, Gathumbi PK, Mbaria JM, Kiama SG. 2014. Medicinal plants used in treatment and management of cancer in Kakamega Country, Kenya. J Ethnopharmacol 151:10401055 .

Ong HC, Ahmad N, Milow P. 2011b. Traditional medicinal plants used by the Temuan Villagers in Kampung Tering, Negeri Sembilan, Malaysia. Ethnol Med 5 (3): 169-173.

Ong HC, Chua S, Milow P. 2011a. Ethno-medicinal plants used by the Temuan Villagers in Kampung Jeram Kedah, Negeri Sembilan, Malaysia. Ethno Med 5 (2): 95-100.

Ong HC, Lina E, Milow P. 2012b. Traditional knowledge and usage of medicinal plants among the Semai Orang Asli at Kampung Batu 16, Tapah, Perak, Malaysia. Stud Ethno-Med 6 (3): 207-211.

Ong HC, Norliah A, Sorayya M. 2012a. Traditional knowledge and usage of edible plants among the Temuan villagers in Kampung Tering, Kuala Pilah, Negeri Sembilan, Malaysia. Indian J Tradit Knowl 11 (1): 161-165

Pham HNT, Vuong QV, Bowyer MC, Scarlett CJ. 2020. Phytochemicals derived from Catharanthus roseus and their health benefit. Technologies 8 (80): 1-16.

Rizki R, Nursyahra, Fernando O. 2019. Study of weeds as traditional medicinal plants used by indigenous people of West Pasaman, Indonesia. J Trop Hortic 2 (2): 81-85.

Sabran ST, Mohamed M, Bakar MFA. 2016. Ethnomedical knowledge of plants used for the treatment of Tuberculosis in Johor, Malaysia. Evid-Based Compl Altern Med 2016: 2850845. DOI: $10.1155 / 2016 / 2850845$

Saynes-Vásquez A, Caballero J, Meave JA, Chiang F. 2013. Cultural change and loss of ethnoecological knowledge among the Isthmus Zapotecs of Mexico. J Ethnobiol Ethnomed 9 (40): 1-10.

Semenya S, Potgieter M.2013. Catharanthus roseus (L.) G. Don.: Extraordinary Bapedi medicinal herb for gonorrhoea. J Med Plant Res7: 1434-1438.

Sharafatmandrad M, Mashizi AK. 2020. Ethnopharmacological study of native medicinal plants and the impact of pastoralism on their loss in arid to semiarid ecosystems of southeastern Iran. Sci Rep 10 (15526): 1-18.

Sulaiman, Shah S, Khan S, Bussmann RW, Ali M, Hussain D, Hussain W. 2020. Quantitative ethnobotanical study of indigenous knowledge on medicinal plants used by the tribal communities of Gokand Valley, District Buner, Khyber Pakhtunkhwa, Pakistan. Plants 9 (1001): 1-29.

Tefera T, Yihune M. 2018. Ethnobotanical study on medicinal plants used by indigenous people in Tenta District, South Wollo, Ethiopia. J Med Plants Res 13 (2): 47-54.

Vo VC. 2012. Dictionary of Vietnamese medicinal plants, Medical Publishing House, Ha Noi. Am J Plant Sci 4: 210-215.

Weckmuller H, Barriocanal C, Maneja R, Boada M. 2019. Factors affecting traditional medicinal plant knowledge of the Waorani, Ecuador. Sustainability 11 (4460): 1-12

Zaki PH, Gandaseca S, Rashidi NM, Ismail MH. 2019. Traditional usage of medicinal plants by Temiar tribes in the state of Kelantan, Peninsular Malaysia. For Soc 3 (2): 227-234. 